Original Article

\title{
ANALYTICAL METHOD VALIDATION OF ICP-AES FOR ANALYSIS OF CADMIUM, CHROMIUM, CUPRUM, MANGAN AND NICKEL IN MILK
}

\author{
DAVID ALEXANDER ${ }^{1}$, ABDUL ROHMAN ${ }^{1,2^{*}}$
}

${ }^{1}$ Faculty of Pharmacy, Gadjah Mada University, Yogyakarta, 55281, Indonesia, ${ }^{2}$ Institute of Halal Industry and Systems (IHIS), Gadjah Mada University, Yogyakarta, 55281, Indonesia

Email: abdul_kimfar@ugm.ac.id

Received: 04 Sep 2018, Revised and Accepted: 24 May 2019

\section{ABSTRACT}

Objective: The aim of this research was to validate inductively coupled plasma-atomic emission spectroscopy (ICP-AES) for quantitative analysis of cadmium (Cd), chromium ( $\mathrm{Cr}$ ), cuprum (Cu), mangan ( $\mathrm{Mn})$ and nickel $(\mathrm{Ni})$ in milk products.

Methods: The heavy metals in milk were determined using ICP-AES at optimized wavelength. The method was validated by assessing several validation parameters which included linearity and range, accuracy, precision and sensitivity expressed by the limit of detection and limit of quantification. The validated method was then used for the analysis of milks commercially available.

Results: ICP-AES for determination of $\mathrm{Cd}, \mathrm{Cr}, \mathrm{Cu}, \mathrm{Mn}$, and $\mathrm{Ni}$ was linear over a certain concentration range with a coefficient correlation value of $>0.997$. The limit of quantification values of $\mathrm{Cd}, \mathrm{Cr}, \mathrm{Cu}, \mathrm{Mn}$, and $\mathrm{Ni}$ were $0.0047 ; 0.0050 ; 0.0066 ; 0.0061 ;$ and $0.0169 \mu \mathrm{g} / \mathrm{ml}$, respectively. The precision of analytical method exhibited relative standard deviation (RSD) values of 3.18\%; 4.17\%; 3.05\%; 2.93\%; and 4.47\% during repeatability test and 5.28\%; 5.06\%; 3.67\%; 3.67\%; and 11.17\% during intermediate precision of $\mathrm{Cd}, \mathrm{Cr}, \mathrm{Cu}, \mathrm{Mn}$, and Ni respectively. The recoveries of these metals assessed using standard addition method were 92.25; 90.88; 102.87; 94.50; and 86.85\%, respectively.

Conclusion: ICP-AES offered a reliable and fast method for the determination of heavy metals in milk products. The developed method could be proposed as an official method for determination of heavy metals in milk products.

Keywords: Validation, ICP-AES, heavy metals, Wet digestion, Milk

(C) 2019 The Authors. Published by Innovare Academic Sciences Pvt Ltd. This is an open access article under the CC BY license (http://creativecommons.org/licenses/by/4.0/) DOI: http://dx.doi.org/10.22159/ijap.2019v11i4.29503

\section{INTRODUCTION}

Milk is one of the most important food products taking into account its protein contents, carbohydrates, fats, enzymes, vitamins and minerals, either macro-minerals like calcium and magnesium or microcomponents such as $\mathrm{Fe}, \mathrm{Zn}$ and $\mathrm{C}$ which are essential to promote the growth and maintenance of human life [1,2]. Milk can carry numerous xenobiotic substances coming from the extrusion of mammary glands, which in turn constitute risk factors [3]. In addition, due to the growing environmental pollution caused by the increase of industrial, agricultural and urban emissions, milk and other dairy products contain different amounts of toxic contaminants including heavy metals [4]. The regulatory agencies have determined the maximum levels of heavy metals allowable to be present in the products.

The heavy metals like cadmium (Cd), chromium $(\mathrm{Cr})$, cuprum $(\mathrm{Cu})$, mangan $(\mathrm{Mn})$ and nickel $(\mathrm{Ni})$ present in high levels resulted some adverse effects on human health because of its cumulative effect. These heavy metals present in milk and other dairy products, even in the low levels, caused metabolic disorders which corresponded to some health problems like heart failure, weakness and cancer. $\mathrm{Cd}$ is reported as one of the toxic metals even at low concentrations and is classified as human carcinogen by International Agency for Research on Cancer [5]. The maximum tolerable daily intake of $\mathrm{Cd}$ in food products is $1.0-1.2 \mu \mathrm{g} / \mathrm{g}$ food. The toxicity of $\mathrm{Cr}$ depends on the oxidation state, while $\mathrm{Cu}$ is linked with certain cancer in animal models [6]. Chromium (III) is one of the essential minerals needed to maintain the function of normal physiological function, while $\mathrm{Cr}(\mathrm{VI})$ is toxic [7]. Mangan (Mn) has been reported to have cumulative properties. The chronic manganese excess can affect in central nervous system, having symptoms similar to Parkinson's disease [8]. The toxic effect of Ni(II) for human has been reported. Nickel could destroy the central nervous system, heart and kidneys, reduced the immunological capacity, eczema, and allergic [9, 10]. As a consequence, the determination of these metals are required to assure the safety of milk and other dairy products.

Milk is widely consumed in the human diet, especially in early childhood, therefore, the control of trace elements in milk via determination of these heavy metals is needed by some regulators. Numerous methods have been used for the determination of heavy metals, namely flame atomic absorption spectrometry [11], graphite furnace atomic absorption spectroscopy [12], inductively coupled plasma-mass spectrometry [12], inductively coupled plasma emission atomic spectrometry [3], inductively coupled plasma optical emission spectrometry [13], atomic fluorescence spectrometry [14], potentiometric stripping analysis [1], stripping potentiometry [15], differential pulse anodic stripping voltammetry technique [16], flow injection spectrometric methods [17], capillary zone electrophoresis [18], polarimetry analysis [19], and the commonly used one is atomic absorption spectrophotometry [20]. The objective of this study was to validate simple ICP-AES for simultaneous determination of cadmium (Cd), chromium (Cr), cuprum (Cu), mangan (Mn) and nickel (Ni) in milk samples.

\section{MATERIALS AND METHODS}

\section{Materials}

Milks from different brands were purchased from the supermarket around Universitas Gadjah Mada Yogyakarta, Indonesia. The standard solutions of cadmium (Cd), chromium $(\mathrm{Cr})$, cuprum $(\mathrm{Cu})$, Mangan $(\mathrm{Mn})$, and nickel $(\mathrm{Ni})$ with concentration of $1000 \mu \mathrm{g} / \mathrm{ml}$ as well as nitric acid $65 \%$ and perchloric acid $70-72 \%$ were purchased from E. Merck (Darmstat, Germany), aquabidestillata was obtained from LPPT Universitas Gadjah Mada, Yogyakarta. Reagents and solvents used were of pre-analytical grade reagents.

\section{Preparation of working solution}

The working solution was prepared by diluting stock solution $(1000$ $\mu \mathrm{g} / \mathrm{ml})$ using diluting solvent $\left(\mathrm{HNO}_{3} 1.5 \%\right)$ to obtain a series of solution of $\mathrm{Cd}, \mathrm{Cu}, \mathrm{Cr}, \mathrm{Mn}$ and $\mathrm{Ni}$ with concentrations of $0.01-1.0$ $\mu \mathrm{g} / \mathrm{ml}$. These solutions were subjected to ICP-AES measurement using the condition as follows, Spectrometer: High resolution echelle polychromator and large format programmable array (L-PAD); RF Generator: $40 \mathrm{MHz}$ free running; Output power: $1.1 \mathrm{~kW}$; Peristaltic 
pump: $1.0 \mathrm{ml} / \mathrm{min}$; Nebulizer: Pneumatic (glass concentric); Spray Chamber: Glass cyclonic.

\section{Sample digestion}

Sample digestion was performed using wet digestion method according to Noviana et al. [21], with slight modification. A-5.0 ml milk was introduced into digestion flask, added with $14 \mathrm{ml}$ of a mixture of $\mathrm{HNO}_{3} 65 \%$ and $\mathrm{HClO}_{4}$ 70-72\% (1:1 v/v). The solution was heated at the hot plate until a clear solution appeared. After cooling, the solution was made until $25.0 \mathrm{ml}$ in a volumetric flask with aquabidestillata.

\section{Validation of the analytical method}

ICP-AES method was validated according to Eurachem guide as in Noviana et al. [21]. Some validation parameters namely linearity, range, sensitivity expressed with a limit of detection and limit of quantification, precision (repeatability and intermediate precision), and accuracy was assessed to evaluate its suitability for the intended use of the used method. The validated method was then used for the analysis of milk samples.

\section{RESULTS AND DISCUSSION}

Analysis of metals of $\mathrm{Cd}, \mathrm{Cr}, \mathrm{Cu}, \mathrm{Mn}$, and $\mathrm{Ni}$ using ICP-AES involved sample destruction using $\mathrm{HNO}_{3}-\mathrm{HClO}_{4}$ as destructive agents. The temperature used during wet digestion was set initially at $130^{\circ} \mathrm{C}$ and then ramped at $200^{\circ} \mathrm{C}$. The digestion was stopped if the solution appear clear. Decomposition of the sample is essentially ensured by a common wet digestion procedure, which is performed under the synergistic effects of elevated temperature; however, heavy metals are stable even in high temperature. ICP-AES method was validated according to Eurachem guideline by evaluating some parameters of linearity and range, sensitivity, precision and accuracy.

The linearity of the analytical method was evaluated by making a series of standard solutions of $\mathrm{Cd}, \mathrm{Cu}, \mathrm{Cr}, \mathrm{Mn}$ and $\mathrm{Ni}$ with certain concentration and correlating between the intensities of light emitted during analysis (y-axis) along with its concentration (x-axis). Each element emitted energy in several wavelengths which are characteristics to the transition from low energy levels into higher energy levels. Analysis of elements using ICP-AES is typically performed using one wavelength which provides maximum sensitivity. Therefore, in this study, some wavelengths were optimized and the selected wavelength was based on its capability to provide the highest slope (maximum sensitivity) and lowest \%-intercept. For example, Cd was measured at three wavelengths, namely $214.438 \mathrm{~nm}$, $226.502 \mathrm{~nm}$, and $228.820 \mathrm{~nm}$. Fig. 1 revealed the relationship between Cd concentration (x-axis) and intensity of light emitted (y-axis), along with the coefficient of correlation (r). The wavelength of $226.502 \mathrm{~nm}$ was selected for further analysis of $\mathrm{Cd}$, as the slope maximum (10483.889) with minimum intercept value (43.339). Table 1 listed the linear regression for the relationship between the concentrations of metals and intensities at optimized wavelength, along with r-value and concentration range. All r-values were higher than 0.99 which indicated that linear relationship existed between concentration and intensities at a certain concentration as in table $1[22]$. In addition, \%intercept values were also low $(<2 \%)$.

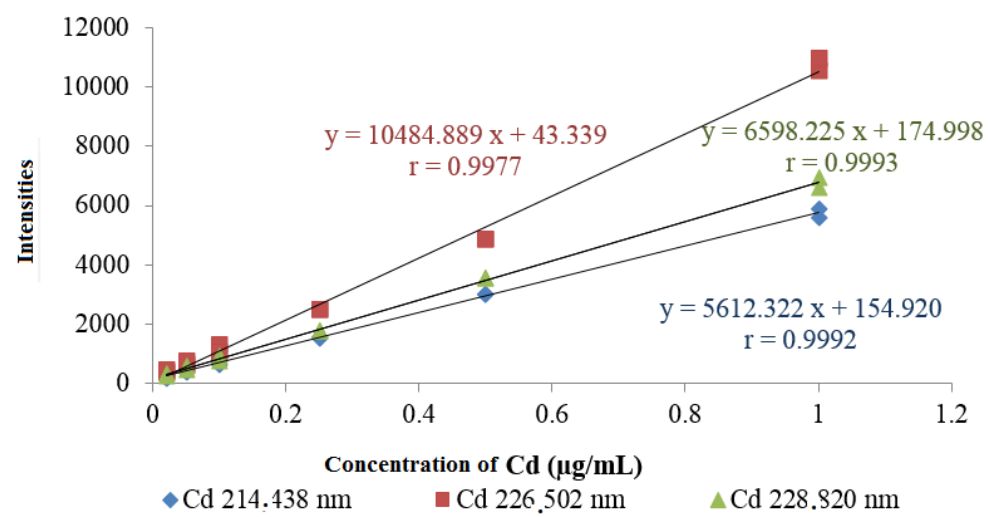

Fig. 1: The relationship between Cd concentration ( $x$-axis) and intensity of light emitted ( $y$-axis) at wavelengths of $214.438 \mathrm{~nm}, 226.502$ $\mathrm{nm}$, and $228.820 \mathrm{~nm}$

Table 1: The linear regression for the correlation between the concentration of metals $(x)$ and intensities $(y)$ at optimized wavelength along with the coefficient of correlation $(r)^{*}$

\begin{tabular}{llll}
\hline Metals & Wavelength & Concentration range $(\boldsymbol{\mu g} / \mathbf{m l})$ & Linear regression \\
\hline $\mathrm{Cd}$ & $226.502 \mathrm{~nm}$ & $0.01-1.0$ & $\mathrm{y}=10483.889 \mathrm{x}+43.339$ \\
$\mathrm{Cr}$ & $267.716 \mathrm{~nm}$ & $0.01-2.0$ & $\mathrm{y}=8413.406 \mathrm{x}-33.868$ \\
$\mathrm{Cu}$ & $324.754 \mathrm{~nm}$ & $0.01-1.0$ & $\mathrm{y}=21882.269 \mathrm{x}-211.435$ \\
$\mathrm{Mn}$ & $257.610 \mathrm{~nm}$ & $0.01-0.5$ & $\mathrm{y}=81355.162 \mathrm{x}+100.877$ \\
$\mathrm{Ni}$ & $221.647 \mathrm{~nm}$ & $0.01-1.0$ & $\mathrm{y}=3964.189 \mathrm{x}+69.398$ \\
\hline
\end{tabular}

*obtained from three replicates $(\mathrm{n}=3)$

The sensitivity of the analytical method was expressed by the limit of detection (LoD) and limit of quantification. The developed method should be revealed LoD values lower than maximum limits of these metals in milk. The detection limits found were $0.0047 \mu \mathrm{g} / \mathrm{ml}, 0.0066$ $\mu \mathrm{g} / \mathrm{ml}, 0.0015 \mu \mathrm{g} / \mathrm{ml}, 0.0018 \mu \mathrm{g} / \mathrm{ml}$ and $0.0051 \mu \mathrm{g} / \mathrm{ml}$ for $\mathrm{Cd}, \mathrm{Cu}, \mathrm{Cr}, \mathrm{Mn}$ and $\mathrm{Ni}$, respectively. In addition, LoQ values were $3.33 \mathrm{x}$ LoD values of corresponding metals. The LoD values were lower than the maximum limits of metals allowed in milk. For example, according to Indonesian standard, the maximum limits of Cd in UHT milk and powder milk were $0.2 \mu \mathrm{g} / \mathrm{g}$ and $20 \mu \mathrm{g} / \mathrm{g}$, respectively, therefore in can be concluded that ICP-AES was sensitive enough for determination of these metals in milk products. The precision of ICP-AES was evaluated by repeatability and intermediate precision using different days of analysis. The relative standard deviation (RSD) values were used for precision evaluation. The method was precise if RSD values obtained were lower than RSD Horwitz. Table 2 compiled RSD values of metals analyzed using the developed method either during repeatability test or during intermediate precision. The maximum RSD horwitz for analyte level of $1.0 \mu \mathrm{g} / \mathrm{ml}$ was $16 \%$. All RSD values during precision studies were lower than $16 \%$ [23], therefore, ICP-AES method was precise enough for quantitative analysis of $\mathrm{Cd}, \mathrm{Cu}, \mathrm{Cr}, \mathrm{Mn}$ and $\mathrm{Ni}$ in milk samples. 
Table 2: The relative standard deviation (RSD) values of $\mathrm{Cd}, \mathrm{Cr}, \mathrm{Cu}, \mathrm{Mn}$, and $\mathrm{Ni}$ in milk analyzed using ICP-AES (n =6)

\begin{tabular}{lll}
\hline Heavy Metals & RSD values (\%) \\
\cline { 2 - 3 } & Repeatability & Intermediate precision \\
\hline $\mathrm{Cd}$ & $2.19 \%$ & $5.28 \%$ \\
$\mathrm{Cr}$ & $3.71 \%$ & $5.06 \%$ \\
$\mathrm{Cu}$ & $3.05 \%$ & $3.67 \%$ \\
$\mathrm{Mn}$ & $2.93 \%$ & $3.67 \%$ \\
$\mathrm{Ni}$ & $5.01 \%$ & $11.17 \%$ \\
\hline
\end{tabular}

The accuracy of the analytical method was evaluated by recovery percentage of analyte added into milk samples using the standard addition method. Three levels of concentrations were used for accuracy studies. Table 3 compiled recovery percentages on metals as analyzed using ICP-AES along with RSD values obtained during three replicates for each levels. Association of Official Analytical
Chemists (AOAC) set up that the recovery percentage of analyte at level $1.0 \mathrm{ppm}$ was in the range of $80-110 \%$ [21], therefore, the recovery percentages obtained using ICP-AES was acceptable, meaning that this method was accurate for determination of metals in milk. It was also stated that systematic errors do not significantly contribute for this method.

Table 3: The recovery percentages of $\mathrm{Cd}, \mathrm{Cr}, \mathrm{Cu}, \mathrm{Mn}$, and $\mathrm{Ni}$ in milk analyzed using ICP-AES ( $\mathrm{n}=3$ for each concentration levels)

\begin{tabular}{lll}
\hline Metals & Recovery percentages* & RSD (\%) \\
\hline $\mathrm{Cd}$ & $92.25 \pm 5.55$ & 6.02 \\
$\mathrm{Cr}$ & $90.88 \pm 2.33$ & 2.56 \\
$\mathrm{Cu}$ & $102.87 \pm 5.21$ & 5.06 \\
$\mathrm{Mn}$ & $94.50 \pm 5.32$ & 5.63 \\
$\mathrm{Ni}$ & $86.85 \pm 6.62$ & 7.62 \\
\hline
\end{tabular}

*expressed as mean \pm SD.

Based on validation parameters evaluated, it can be concluded that ICP-AES was valid for quantitative analysis of $\mathrm{Cd}, \mathrm{Cu}, \mathrm{Cr}, \mathrm{Mn}$ and $\mathrm{Ni}$ in milk samples. The validated ICP-AES method was then used for analysis of these metals in milik products, and the results were compiled in table 4 . All milk products evaluated meet the standard, i.e. below the maximum concentration allowed by Indonesia standard.

Table 4: The concentration of $\mathrm{Cd}, \mathrm{Cr}, \mathrm{Cu}, \mathrm{Mn}$, and $\mathrm{Ni}$ in milk samples as analyzed using ICP-AES ${ }^{* *}$

\begin{tabular}{lllll}
\hline Samples & Cd (mg/l) & Cr (mg/l) & Cu (mg/l) & Mn (mg/l) \\
\hline IC & $0.3374 \pm 0.0022$ & $0.1933 \pm 0.0026$ & $0.4877 \pm 0.0090$ & $0.6682 \pm 0.0039$ \\
IV & $0.2380 \pm 0.0018$ & $0.1344 \pm 0.0037$ & $0.1693 \pm 0.0028$ & $0.0288 \pm 0.0037$ \\
FS & $0.2495 \pm 0.0056$ & $0.1484 \pm 0.0033$ & $0.1857 \pm 0.0041$ & $0.1063 \pm 0.0023$ \\
US & $0.2637 \pm 0.0019$ & $0.1310 \pm 0.0039$ & $0.1674 \pm 0.0008$ & $0.0324 \pm 0.0029$ \\
UV & $0.3175 \pm 0.0012$ & $0.1665 \pm 0.0078$ & $0.2033 \pm 0.0171$ & nd \\
\hline
\end{tabular}

*nd = not detected; $* *$ the concentrations of heavy metals were expressed as mean \pm SD from three replicates $(\mathrm{n}=3)$.

\section{CONCLUSION}

Inductively coupled plasma-atomic emission spectroscopy has been successfully validated and used for the analysis of metals $(\mathrm{Cd}, \mathrm{Cu}, \mathrm{Cr}$, $\mathrm{Mn}$, and $\mathrm{Ni}$ ) in milk products. The validation parameters meet the requirement. The levels of these metals in milk products were lower than those required by Indonesian standard.

\section{ACKNOWLEDGMENT}

The authors thank to Faculty of Pharmacy and Integrated Laboratory for Research and Testing, Universitas Gadjah Mada (LPPT-UGM) for financial and instrument supports during this study. Mrs. Astuti from LPPT-UGM was acknowledged for assisting instrument operation and monitoring. The publication of this article was supported by Penelitian Terapan Unggulan Perguruan Tinggi (PTUPT) 2019, Tinggi (PTUPT) 2019, 2717/UN1.DITLIT/DITLIT/LT/2019 awarded to Prof. Dr. Abdul Rohman.

\section{AUTHORS CONTRIBUTIONS}

DA and AR performed research activities and prepared manuscript. AR designed research, analyzed data, and made critical thinking on the manuscript.

\section{CONFLICTS OF INTERESTS}

All authors have none to declare

\section{REFERENCES}

1. Suturovic Z, Kravic S, Milanovic S, Đurovic A, Brezo T. Determination of heavy metals in milk and fermented milk products by potentiometric stripping analysis with the constant inverse current in the analytical step. Food Chem 2014;155:120-5.

2. Khan N, Jeong IS, Hwang IM, Kim JS, Choi JS, Nho EY, et al. Analysis of minor and trace elements in milk and yogurts by inductively coupled plasma-mass spectrometry (ICP-MS). Food Chem 2014;147:220-4

3. Pilarczyk R, Wojcik J, Czerniak P, Sablik P, Pilarczyk B, Tomza Marciniak A. Concentrations of toxic heavy metals and trace elements in raw milk of simmental and holstein-friesian cows from organic farm. Environ Monitor Asses 2013;185:8383-92.

4. Kazi TG, Jalbani N, Baig JA, Kandhro GA, Afridi HI, Arain MB. Assessment of toxic metals in raw and processed milk samples using electrothermal atomic absorption spectrophotometer. Food Chem Toxicol 2009;47:2163-9.

5. Zhai Y, Liu Y, Chang X, Chen S, Huang X. Selective solid-phase extraction of trace cadmium (II) with an ionic imprinted polymer prepared from a dual-ligand monomer. Anal Chim Acta 2007;593:123-8.

6. Sarker KC, Ullaha MR. Determination of trace amount of copper (Cu) using Uv-Vis spectrophotometric method. Int J Sci Res Manag 2013;1:23-44.

7. Narayana B, Cherian T. Rapid spectrophotometric determination of trace amounts of chromium using variamine blue as a chromogenic reagent. J Braz Chem Soc 2005;16:197-201.

8. Marbaniang DG. Spectrophotometric determination of manganese in groundwater in shillong city using bismuthate oxidation method. Int J Environ Protec 2012;2:22-6. 
9. Barreto WJ, Barreto SRG, Scarminio IS, Ishikawa DN, de FátimaSoares M, de Proença MVB. Determination of Ni(II) in metal alloys by spectrophotometry uv-vis using dopasemiquinone. Quimica Nova 2010;33:109-13.

10. Tajkarimi M, Ahmadi Faghih M, Poursoltani H, Salah Nejad A, Motallebi AA, Mahdavi H. Lead residue levels in raw milk from different regions in Iran. Food Control 2008;19:495-8.

11. Maas S, Lucot E, Gimbert F, Crini N, Badot PM. Trace metals in raw cow's milk and assessment of transfer to Comte cheese. Food Chem 2011;129:7-12.

12. Abdulkhaliq A, Swaileh KM, Hussein RM, Matani M. Levels of metals $(\mathrm{Cd}, \mathrm{Pb}, \mathrm{Cu}$ and $\mathrm{Fe})$ in cow's milk, dairy products and hen's eggs from the West Bank, Palestine. Int Food Res J 2012;19:1089-94.

13. Kira CS, Maihara VA. Determination of major and minor elements in dairy products through inductively coupled plasma optical emission spectrometry, after wet partial digestion and neutron activation analysis. Food Chem 2007;100:390-5.

14. Patricia Cava Montesinos M, Rodenas Torralba E, Morales Rubio A, Luisa Cervera M, de la Guardia M. Cold vapour atomic fluorescence determination of mercury in milk by slurry sampling using multi-commutation. Anal Chimica Acta 2004;506:145-53.

15. Muñoz E, Palmero S. Determination of heavy metals in milk by potentiometric stripping analysis using a home-made flow cell. Food Control 2004;15:635-41.
16. Tripathi RM, Raghunath R, Sastry VN, Krishnamoorthy UTM. Daily intake of heavy metals by infants through milk and milk products. Sci Total Environ 1999;227:229-35.

17. Nogueira Rita de Araujo A, Mockiuti F, Batista de Souza G, Primavesi 0. Flow injection spectrophotometric catalytic determination of iodine in milk. Anal Sci 1998;14:559-64.

18. Suárez Luque $S$, Mato $\mathrm{I}$, Huidobro JF, Simal Lozano J. Determination of major metal cations in milk by capillary zone electrophoresis. Int Dairy J 2007;17:896-901.

19. Syroeshkin AV, Pleteneva TV, Uspenskaya UV, Levitskaya OV, Tribot Laspiere MA, Zlatsky IA, et al. Polarimetric research of pharmaceutical substances in aqueous solutions with different water isotopologues ratio. Int J Appl Pharm 2018;10:243-8.

20. Saeed AM, Hamzah MJ, Ahmed NQ. Quantitative assay of aspirin and (salicylic acid and heavy metals as impurities) in Iraqi's market aspirin tablets using different analytical methods. Int J Appl Pharm 2018;10:167-72.

21. Noviana E, Pranowo HD, Astuti A, Rohman A. Validation of mercury analyzer for the determination of mercury in snake fruit. Int Food Res J 2012;18:933-6.

22. Miller JN, Miller JC. Statistics and chemometrics for analytical chemistry, Prentice Hall, England; 2010.

23. Gonzalez AG, Herrador MA. A practical guide to analytical method validation, including measurement uncertainty and accuracy profiles. Trends Anal Chem 2007;26:227-38. 